\title{
ANALYTIC DASHBOARD UNTUK PENILAIAN CAPAIAN KINERJA DENGAN METODE SMART DECISION SUPPORT SYSTEM
}

\author{
Kasim \\ Teknik Komputer dan Jaringan, Politeknik Negeri Ujung Pandang \\ Email:kasim@poliupg.ac.id
}

\begin{abstract}
ABSTRAK
Salah satu implementasi Business Intelligence (BI) di dunia bisnis adalah penerapan dashboard secara real time untuk mengawasi kinerja organisasi. Dashboard analytic melibatkan metode Decision Support System untuk pendukung pengambilan keputusan sesuai kebutuhan organisasi. Untuk mengawasi kinerja unit kerja, pimpinan adalah salah satu aktor yang paling andil dalam memonitoring dan mengambil kebijakan. Pada penelitian ini, data alternatif yang digunakan adalah data capaian kinerja Unit Kerja PNUP selama tiga triwulan yang terdiri dari dua kriteria dan 13 indikator/output. Metode Decision Support System yang digunakan adalah metode Simple Multi Attribute Rating Technique atau SMART. Sistem yang dibangun merupakan sistem analytic dashboard berbasis web menggunakan framework CodeIgniter.Berdasarkan hasil penelitian, pengguna atau pimpinan dapat mengawasi perkembangan kinerja capaian Unit Kerja. Peringkat indikator kinerja yang baik dalam capaian kinerja adalah $100 \%-75 \%$, sedangkan untuk $74 \%$ ke bawah menunjukkan bahwa indikator kinerja perlu ditinjau ulang dari kesiapan unit kerja serta kesesuaian kemampuan unit kerja dengan target yang diberikan. Peringkat indikator dengan nilai terendah dan tertinggi menjadi pertimbangan dalam rekomendasi hasil keputusan sistem dalam mengambil kebijakan terkait capaian kinerja. Sistem analytic dashboard ini merupakan salah satu konsep BI dalam penentu kebijakan yang dapat diimplementasikan dalam keperluan organisasi.
\end{abstract}

Kata Kunci: analytic, dashboard,kinerja, SMART, DSS, BI

\section{ABSTRACT}

One of the implementation of Business Intelligence (BI) in the business world is the implementation of dashboards in real time to oversee organizational performance. The analytic dashboard involves the Decision Support System method for supporting decision making according to the needs of the organization. To oversee the work unit's performance, the leader is one of the most contributing actors in monitoring and taking policies. In this study, the alternative data used is the performance data of the PNUP Work Unit performance for three quarters consisting of two criteria and 13 indicators / output. The Decision Support System method used is the method of Simple Multi Attribute Rating Technique or SMART. The system built is a web-based analytic dashboard system using the CodeIgniter framework. Based on the results of the study, users or leaders can monitor the progress of the performance of the Work Unit. The ranking of good performance indicators in performance achievement is $100 \%-75 \%$, while for $74 \%$ down indicates that performance indicators need to be reviewed from the readiness of the work unit and the suitability of the work unit's capabilities to the targets provided. The ranking of indicators with the lowest and highest values is considered in the recommendations of the results of system decisions in making policies related to performance achievements. This analytic dashboard system is one of the BI concepts in policy makers that can be implemented in organizational needs.

Keywords: analytic, dashboard,performance, SMART, DSS, BI 


\section{PENDAHULUAN}

Penggunaan kemajuan teknologi informasi yang diintegrasikan dengan proses pekerjaan di suatu organisasi telah menjadi kebutuhan yang sangat penting. Mayoritas Civil Society Organization responden menunjukkan bahwa teknologi komunikasi telah memfasilitasi kinerja internal manajemen mereka secara sangat signifikan $(46,98 \%)$ dan signifikan (40\%)[1]. Penggunaan tersebut juga mempengaruhi tujuan dan aktivitas organisasi $(44,04 \%)$ atau jauh lebih terfokus $(32,57 \%)$. Ketersediaan data dan informasi yang benar dan tepat sudah menjadi kebutuhan pokok bagi kelangsungan hidup suatu organisasi. Business Intelligence (BI) merupakan salah satu bentuk implementasi yang mampu menjawab kebutuhan organisasi tersebut. BI telah banyak digunakan oleh organisasi dalam upaya meningkatkan kinerja, mengelola data dan informasi hingga pengambilan keputusan.

Survei yang dilakukan Forrsights Software, North American and European pada tahun 2011 menunjukkan implementasi BI memiliki kedudukan tertinggi $26 \%$ diantara 13 pendukung pembuat kebijakan di perusahaan mereka. Business Intelligence yang lebih kecil mengacu hanya pada lapisan paling atas dari susunan arsitektural BI seperti pelaporan, analitis dan dashboard [2]. Format ini dicapai oleh sistem Bussines Inteligence (BI) dengan penggunaan visualisasi berbagai chart dalam suatu halaman presentasi. Secara umum, fungsi utama BI adalah memberikan informasi secara berkala dalam bentuk laporan maupun dashboard. Peluang BI di indonesia sangat baik kedepannya. Namun penerapan BI saat ini masih terbilang minim dilakukan karena kurangnya kesiapan dan perencanaan dalam merumuskan konsep BI untuk organisasi di bidang TI serta dukungan dan konsistensi pimpinan terhadap proyek BI itu sendiri [3]. Penggunaan TI dalam organisasi hanya sebatas untuk keperluan operasional, seperti untuk mencatat administrasi, rekam data pegawai, dan gaji pegawai.

Berdasarkan kendala diatas, permasalahan mengenai penerapan BI dapat diselesaikan dengan membangun sebuah sistem yang menganut salah satu komponen atau unsur yang terlibat dalam konsep BI sebagai software decisionmaker. Sistem ini merupakan sistem analytic dashboard yang nantinya dapat membantu pihak organisasi untuk mulai menerapkan konsep BI sederhana serta mengawasi jalannya kegiatan organisasi oleh pimpinan dalam suatu organisasi. Oleh karena itu penulis membangun sistem analyticdashboard menggunakan salah satu metode Decision Support System yaitu metode SMART untuk penilaian capaian kinerja.

Berdasarkan permasalahan yang telah diurai, maka masalah yang dibahas adalah bagaimana membangun sistem analityc dashboard untuk penilaian capaian kinerja dengan menerapkan salah satu konsep Business Inteligence, yaitu Key Performance Indicator (KPI) menggunakan metode SMART Decision Support System berbasis web.

\section{TINJAUAN PUSTAKA}

\subsection{Dashboard}

Dashboard adalah satu kategori dari aplikasi Business Intelligence (BI)yang secara real time akan memonitoringberbagai informasi yang 
dibutuhkan oleh suatu organisasi atau perusahaan dengan berbagai macam format seperti graphical gadgets, typically, gauges, charts, indicators, dan colorcoded maps yang memungkinkan mereka membuat keputusan secara cepat [4].

\subsection{Repository}

Business Intelligence adalah kumpulan model matematika dan metodologi analisa yang secara sistematik menghasilkan data untuk menghasilkan suatu informasi dan pengetahuan yang berguna untuk mendukung proses pengambilan keputusan yang kompleks [5].

Salah satu tool yang digunakan BI adalah dashboard, yang merupakan tampilan visual dari informasi penting yang disajikan pada satu tampilan layar komputer. Tujuan Business Intelligence yaitu membantu manusia dalam pengambilan keputusan, oleh karena itu BI merupakan decision support.

\subsection{Key Performance Indicator (KPI)}

Key Performance Indicator atau disingkat KPI adalah metrik finansial ataupun non-finansial yang digunakan untuk membantu suatu organisasi atau perusahaan untuk menentukan dan mengukur kemajuan terhadap sasaran organisasi atau perusahaan tersebut [6].

Dashboard hanya menyajikan KPI yang mendukung kebutuhan pengguna dalam membuat keputusan atau tindakan bisnis. Pengambilan keputusan akan lebih efisien jika dilakukan dengan Decision Support System.

\subsection{Kinerja}

Kinerja adalah seberapa banyak para pekerja memberi konstribusi kepada perusaha -an meliputi kuantitas output, kualitas output, jangka waktu, kehadiran ditempat kerja dan sikap kooperatif [7].

KOMPONEN DAN INTERVAL PENILAIAN KINERJA PTN SATKER KOPERTIS

a) Nilai Kerja Fisik

Gap/Delta antara Target Output (fisik) vs Realisasi fisik

Bobot : $70 \%$

$\begin{array}{ll}0 \%-10 \% & =100 \\ >10 \%-20 \% & =90 \\ >20 \%-30 \% & =85 \\ >30 \%-40 \% & =80 \\ >40 \% & =75 \\ \text { Tidak mengisi } & =30\end{array}$

b) Nilai Kerja Anggaran

Gap/Delta antara Target Output (fisik) $v s$ Realisasi anggaran

Bobot : $30 \%$

$\begin{array}{ll}0 \%-10 \% & =100 \\ >10 \%-20 \% & =90 \\ >20 \%-30 \% & =85 \\ >30 \%-40 \% & =80 \\ >40 \% & =75 \\ \text { Tidak mengisi } & =30\end{array}$

PENILAIAN CAPAIAN KINERJA UNIT KERJA (SESUAI PERMEN 31/2016)

Tabel 2.1: Interval Nilai Kinerja Capaian Unit Kerja

\begin{tabular}{|r|c|c|}
\hline No & $\begin{array}{c}\text { Nilai Kinerja } \\
\text { Unit Kerja }\end{array}$ & $\begin{array}{c}\text { Nilai Capaian } \\
\text { Kinerja Unit } \\
\text { Kerja }(\%)\end{array}$ \\
\hline 1 & $90-100$ & 100 \\
\hline 2 & $85-89,99$ & 95 \\
\hline 3 & $80-84,99$ & 90 \\
\hline 4 & $75-79,99$ & 85 \\
\hline 5 & $70-74,99$ & 80 \\
\hline 6 & $65-69,99$ & 75 \\
\hline 7 & $60-64,99$ & 70 \\
\hline 8 & 59,99 ke & 65 \\
\hline
\end{tabular}




\subsection{Decision Support System (DSS)}

Decision Support System (DSS) adalah sistem berbasis komputer yang menyajikan dan memproses informasi yang memungkin -kan pembuatan keputusan menjadi lebih produktif, dinamis dan inovatif[8]. Tujuan DSS dalam pengambilan keputusan bukan menggantikan manajer melainkan alat yang mendukung manajer dalam mengambil keputusan.

DSS memberikan manfaat yang sangat besar dalam menganalisa data dan membantu pengambilan keputusan suatu instansi atau perusahaan. Adapun dalam pengimplementasi -annya digunakan metode-metode DSS untuk menentukan keputusan yang lebih berbobot. Salah satu metode DSS yang dapat digunakan adalah metode SMART.

\subsection{Simple Multi Attribute Rating Technique (SMART)}

Simple Multi Attribute Rating Technique (SMART) merupakan teknik pengambilan keputusan yang didasarkan pada teori bahwa setiap alternatif terdiri dari sejumlah kriteria yang memiliki nilainilai dan setiap kriteria memiliki bobot yang menggambarkan seberapa penting ia dibandingkan dengan kriteria lain [8].

$$
u\left(a_{i}\right)=\sum_{J=1}^{m} n w_{j} . u_{i}\left(a_{i}\right) \ldots \ldots(I I .1)
$$

Keterangan:

$n w_{j}=$ nilai pembobotan kriteria ke-j dan $k$ kriteria

$u_{i}\left(a_{i}\right)=$ nilai utility kriteria ke- $i$ untuk kriteria ke- $i$

$u\left(a_{i}\right)=$ nilai total alternatif

Untuk mendapatkan nilai pada persamaan (II.1), nilai yang dihitung terlebih dahulu adalah nilai normalisasi bobot dari setiap kriteria dengan membandingkan nilai bobot kriteria dengan jumlah bobot kriteria, menggunakan rumus persamaan (II.2) berikut.

$$
n w_{j}=\frac{w_{j}}{\sum w_{j}} \ldots \ldots
$$

Keterangan:

$n w_{j}$ : normalisasi bobot kriteria ke $j$

$w j$ : nilai bobot kriteria ke $j$

$\sum w_{j}$ : bobot kriteria ke $m$

Setelah normalisasi bobot kriteria dilakukan, dilanjutkan dengan menghitung nilai utility dengan persamaan sebagai berikut.

$$
u_{i}\left(a_{i}\right)=\frac{C_{\text {out }}-C_{\min }}{C_{\max }-C_{\min }} 100 \% \ldots \ldots .
$$

Keterangan:

$u_{i}\left(a_{i}\right)$ : nilai utility kriteria ke-i untuk kriteria ke- $i$

$C_{\max }:$ nilai kriteria maksimal

$C_{\min }:$ nilai kriteria minimal

$C_{\text {out }} \quad$ : nilai kriteria ke $i$

\section{METODE PENELITIAN}

Metode penelitian pada jurnal ini terdiri dari :

\subsection{Prosedur Penelitian}

Prosedur dalam penelitian diperlukan agar penelitian ini dapat terstruktur sehingga hasil yang nantinya diperoleh sesuai dengan tujuan pada penelitian. Adapaun tahapan prosedur penelitian ini dibuat berdasarkan pengembang -an rekayasa perangkat lunak air terjun (waterfall).

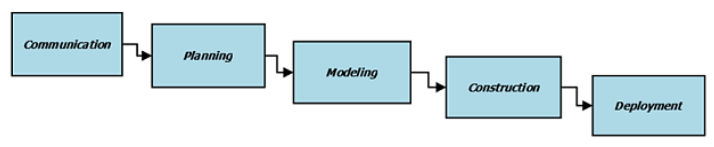

Gambar 3.1 Prosedur Penelitian (Metode Waterfall, Pressman 2015). 


\section{1) Communication}

Hasil dari tahapan ini adalah mengidentifi -kasi data dan proses, serta tampilan pada sistem yang akan dibuat.

a) Data yang digunakan sebagai sampel data adalah data kinerja Unit Kerja PNUP selama beberapa triwulan.

b) Wawancara dilakukan pada Bagian Unit Perencanaan PNUP dalam hal ini pegawai yang bertanggung jawab mengelola data capaian kinerja.

c) Studi literatur dari jurnal, skripsi/tesis/disertasi serta sistem informasi yang telah ada yang berhubungan dengan penilaian kinerja dan metode-metode pengambilan keputusan.

\section{2) Planning}

Tahapan ini adalah tahap analisis kebutuhan ini dilakukan yang agar tahap perancangan sistem dapat dibangun sesuai dengan tahapan pengumpulan data yang sebelumnya telah dilakukan. Kebutuhan tersebut berupa 8 modul dan sebuah metode pengambilan keputusan sebagai umpan balik dari hasil capaian untuk mendukung pimpinan dalam menentukan kebijakan.

Adapun 8 modul tersebut yaitu modul login, modul admin, modul user, modul home/dashboard, modul triwulan, modul capaian, modul hasil dan modul smart. Kebutuhan sistem antara lain menetapkan standar pengukuran, mengumpulkan data-data atau sampel yang diperlukan serta menganalisa perbandingan standar kinerja dan hasil yang dicapai menggunakan metode pengambilan keputusan.
3) Modeling

Dari penjelasan tahap Communication, dapat digambarkan rancangan dekomposisi data (database) ke dalam suatu Entity Relationship Diagram (ERD) seperti Gambar 3.2.

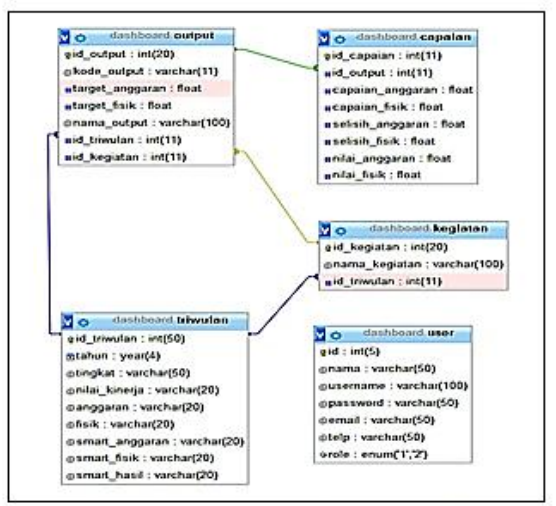

Gambar 3.2 Entity Relational Diagram (ERD) Database 'Dashboard'|

Pada Gambar 3.3 dibawah ini, activity diagram menggambarkan aktivitas administrator, user (pimpinan), dan sistem.

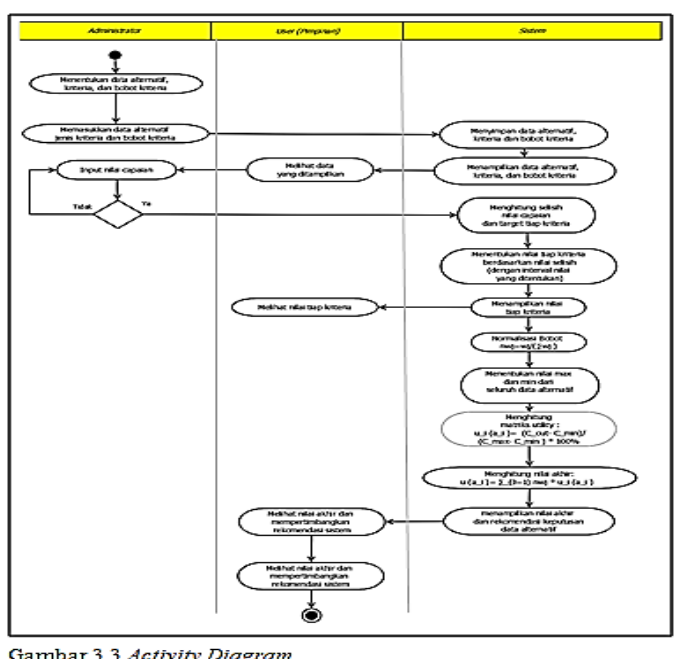

Adapun diagram pada Gambar Use case diagram berikut ini menunjukkan kebutuhan fungsionalitas sistem dan bagaimana sistem tersebut berinteraksi dengan dunia luar dalam sistem analytic dashboard.

4) Construction

Adapun pada sistem pemrograman, dimasukkan metode perhitungan SMART. Hasil evaluasi dari 
perhitungan metode akan ditampilkan di dashboard. Pada sistem ini terdapat 8 class, yaitu class User, class Admin, class Home, class Triwulan, class Capaian, dan class Hasil.

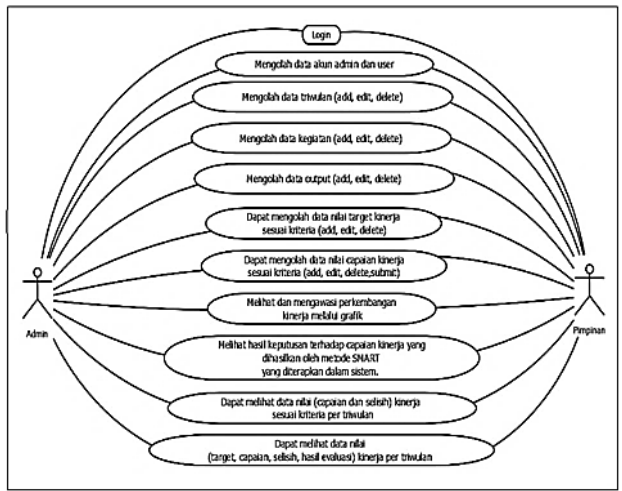

Gambar 3.4. Diagram use case

\section{5) Deployment}

Metode DSS yang diterapkan mengelola kriteria dan nilai dari setiap kriteria dengan menggunakan metode SMART serta memberikan laporan dalam bentuk grafik ranking atau peringkat personel terbaik.

\section{HASIL DAN PEMBAHASAN}

Berdasarkan perancangan tersebut, maka telah dilakukan implementasi, pengujian fungsionalitas sistem dan evaluasi sistem yang bertujuan untuk mengetahui tingkat keberhasilan sistem dalam proses verifikasi dan penggunaannya.

\section{1) Pengujian LoginUser}

\begin{tabular}{|c|c|c|c|c|}
\hline No. & Data Masukan & Yang Diharapkan & Pengamatan & Hasil \\
\hline 1. & $\begin{array}{l}\text { Memasukkan } \\
\text { Username dan } \\
\text { Passwordyang } \\
\text { benar }\end{array}$ & $\begin{array}{l}\text { Login berhasil dan } \\
\text { masuk kehalaman } \\
\text { utama. }\end{array}$ & $\begin{array}{l}\text { Admin dan user dapat } \\
\text { masuk ke kehalaman } \\
\text { utama sistem dan } \\
\text { melakukan pekerjaan } \\
\text { sesuai hak aksesnya. }\end{array}$ & Berhasil \\
\hline 2. & $\begin{array}{l}\text { Memasukkan } \\
\text { Username dan } \\
\text { Passwordyang } \\
\text { salah }\end{array}$ & $\begin{array}{l}\text { Login gagal dan } \\
\text { munculpesan } \\
\text { "Usernamel } \\
\text { Password salah"" }\end{array}$ & $\begin{array}{l}\text { Admin dan Usertidak } \\
\text { dapat masukke } \\
\text { halamanutama } \\
\text { sistem danmucul } \\
\text { pesan "Username/ } \\
\text { Password salah!" }\end{array}$ & Berhasil \\
\hline
\end{tabular}

\section{2) Pengujian Side Dashboard}

\begin{tabular}{|c|c|c|c|c|}
\hline No. & Data Masukan & \begin{tabular}{|l} 
Yang Diharapkan \\
\end{tabular} & Pengamatan & Hasil \\
\hline 1. & $\begin{array}{l}\text { Menampilkan } \\
\text { chart barnilai } \\
\text { per triwulan }\end{array}$ & $\begin{array}{l}\text { Sistem } \\
\text { menampilkan chart } \\
\text { barnilai hasil } \\
\text { evaluasi per } \\
\text { trivulan }\end{array}$ & $\begin{array}{l}\text { Sistemmenampilkan } \\
\text { chart bar nilai hasil } \\
\text { evaluasi pert trivulan } \\
\text { pada dashboard }\end{array}$ & Berhasil \\
\hline 2. & $\begin{array}{l}\text { Menampilkan } \\
\text { chart bar nilai } \\
\text { nilai kineja } \\
\text { anggarandan } \\
\text { kinerja fisikper } \\
\text { triwulan }\end{array}$ & $\begin{array}{l}\text { Sistem } \\
\text { menampillkan chart } \\
\text { barnilai nilai } \\
\text { kinerja anggaran } \\
\text { dankinerja fisik per } \\
\text { triwulan }\end{array}$ & $\begin{array}{l}\text { Menanpilkan chart } \\
\text { bar nilai nilai kinerja } \\
\text { anggarandankinerja } \\
\text { fisils per trivulan } \\
\text { pada dashboard. }\end{array}$ & Berhasil \\
\hline 3 & $\begin{array}{l}\text { Menampilkan } \\
\text { nilai kriteria } \\
\text { danpemyataan } \\
\text { (keputusan) } \\
\text { sesuai datanilai } \\
\text { capaian }\end{array}$ & \begin{tabular}{|l|} 
Sistem \\
menampilkannilai \\
kniteria dan \\
pemyataan \\
(keputusan) \\
keputusansesuai \\
data nilai capaian
\end{tabular} & $\begin{array}{l}\text { Sistemmenampilkan } \\
\text { nilai kriteria dan } \\
\text { pemyataan } \\
\text { (keputusan) } \\
\text { keputusansesuai data } \\
\text { nilai capaianpada } \\
\text { dashboard. }\end{array}$ & Berhasil \\
\hline
\end{tabular}

\section{3) Pengujian Side Manajemen}

Tabel 4.3 Pengujian Side Mangjemen

\begin{tabular}{|l|l|l|l|l|}
\hline No. & Data Masukan & Yang Diharapkan & \multicolumn{1}{|c|}{ Pengamatan } & Hasil \\
\hline & Menambahkan & Data admin & \\
& data admin ka & Data admin & bartambah sesuai & \\
1. & bistem pada & bertambah sesuai & dengan data yang & Barhasil \\
& mangjemen & dengan data yang & dimasulkian dan & \\
& admin & dimasulkan & ditampilkan pada & \\
\hline
\end{tabular}

\section{4) Pengujian Side Dashboard}

\begin{tabular}{|c|c|c|c|c|}
\hline No. & Data Masukan & Yang Diharapkan & Pengamatan & Hasil \\
\hline 1. & \begin{tabular}{|l|} 
Tampilan awal \\
Side Nilai \\
Capaian \\
menampillsan \\
daftar triwulan
\end{tabular} & \begin{tabular}{|l} 
Sistem \\
mensmpillkan \\
halaman daftar \\
triwulan sesuai \\
tingksatnya.
\end{tabular} & $\begin{array}{l}\text { Sistem menampillan } \\
\text { halaman daftar } \\
\text { triwulan sesuai } \\
\text { tingkstnya pads Side } \\
\text { Nilai Capaian. }\end{array}$ & Berhasil \\
\hline 2. & $\begin{array}{l}\text { Menampillsan } \\
\text { data nilai datsil } \\
\text { satu triwulan } \\
\text { secara } \\
\text { keseluruhan }\end{array}$ & \begin{tabular}{|l} 
Sistem \\
menampillkan data \\
nilai dettail satu \\
triwulan secara \\
keseluruhan.
\end{tabular} & $\begin{array}{l}\text { Sistem menampillkan } \\
\text { data nilai detsil satu } \\
\text { triwulan secara } \\
\text { keseluruhan. }\end{array}$ & Berhasil \\
\hline 3. & $\begin{array}{l}\text { Menampillkan } \\
\text { katerangan nilai } \\
\text { output yang } \\
\text { belum diinput }\end{array}$ & \begin{tabular}{|l|} 
Sistem \\
menampilkan \\
'belum ada nilai' \\
pada baris output \\
yang belum \\
memiliki nilai
\end{tabular} & $\begin{array}{l}\text { Sistem menampilkan } \\
\text { 'belum ada nilai' } \\
\text { pada baris output } \\
\text { yang belum memiliki } \\
\text { nilsi. }\end{array}$ & Berhasil \\
\hline 4. & $\begin{array}{l}\text { Menghitung } \\
\text { nilsi kinerja } \\
\text { sesuai } \\
\text { ketentuan bobot } \\
\text { nilai }\end{array}$ & $\begin{array}{l}\text { Sistem } \\
\text { mensmpillkan nilai } \\
\text { kinerja angegran } \\
\text { dan nilai kinerja } \\
\text { fisik sesuai } \\
\text { katentuan bo bot } \\
\text { nilai pada halaman } \\
\text { bawah tabel hasil } \\
\text { evaluasi. }\end{array}$ & $\begin{array}{l}\text { Sistem menampillkan } \\
\text { nilai kinerja anggaran } \\
\text { dan nilai kinerja fisik } \\
\text { sasuai katentuan } \\
\text { bobot nilai pada } \\
\text { halaman bawah tabel } \\
\text { hasil }\end{array}$ & Berhasil \\
\hline
\end{tabular}


5) Hasil Perhitungan Nilai Kinerja Unit Kerja

a. Penentuan Nilai Kriteria Sesuai Kebutuhan Organisasi

Masing-masing kriteria akan tercapai dengan indikator kinerja yang ditentukan. Ada 13 indikator (dapat dilihat pada Gambar 4.24) yang harus dicapai untuk memenuhi kedua kriteria tersebut

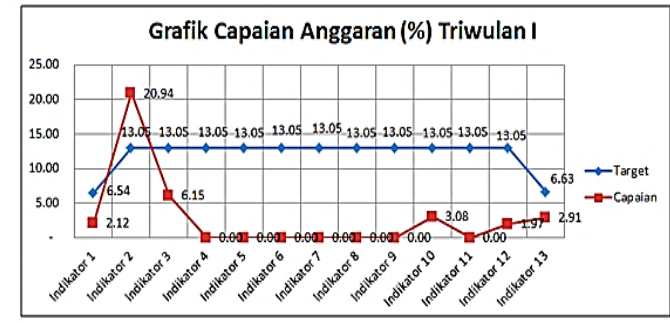

Gambar 4.24 Grafik Capaian Triwulan 1, Kriteria Kinerja Anggaran

Dari grafik pada Gambar 4.25 berikut, didapatkan nilai selisih antara nilai capaian dan target yang ditentukan. Dari nilai selisih tersebut akan diperoleh nilai kriteria.

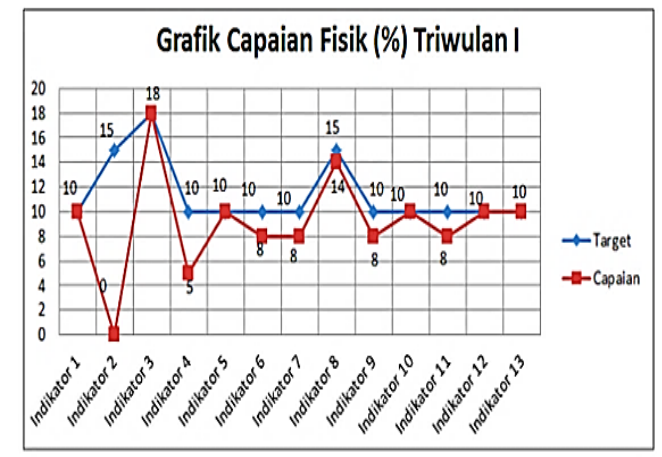

Gambar 4.25 Grafik Capaian Triwulan 1, Kriteria Kinerja Fisik

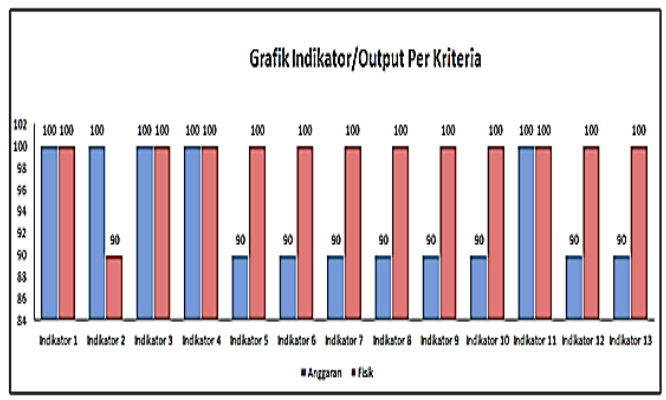

Gambar 4.26 Grafik Indikator/Output Per Kriteria
Dari data grafik berikut (Gambar 4.26), akan diperoleh nilai kriteria sebagai berikut:

Nilai Kriteria Anggaran $=\frac{100+100+100+100+90+90+90+90+90+90+100+90+90}{13}$

$$
=93,85
$$

Nilai Kriteria Fisik $=\frac{100+90+100+100+100+100+100100+100+100+100+100+100}{13}$

$$
=99,23
$$

Kedua nilai kriteria diatas digunakan dalam penentuan nilai capaian kinerja Unit Kerja PNUP dan dibandingkan dengan penentuan nilai metode SMART.

b. Perhitungan metode SMART

Tabel 4.6 Data Altematif dan Bobot Kriteria

\begin{tabular}{|l|l|c|}
\hline \multirow{2}{*}{ Alternatif 2017 } & \multicolumn{2}{|c|}{ Kriteria } \\
\cline { 2 - 3 } & Anggaran & Fisik \\
\hline Triwulan 1 & 93,85 & 99,23 \\
\hline Triwulan 2 & 88,85 & 97,31 \\
\hline Triwulan 3 & 80,77 & 86,54 \\
\hline
\end{tabular}

\begin{tabular}{|c|c|c|}
\hline No & Kriteria & Bobot \\
\hline 1 & Anggaran & $30 \%$ \\
\hline 2 & Fisik & $70 \%$ \\
\hline
\end{tabular}

\section{- Perhitungan Normalisasi Bobot} Kriteria

Normalisasi Bobot Anggaran $=30 \% /$ $100 \%=0,3$;

Normalisasi Bobot Fisik $=70 \% / 100 \%$ $=0,7$;

\section{- Menghitung Nilai Matriks Utility}

Nilai Maksimal (Anggaran) $=\{93,85$; $88,85 ; 80,77\}=93,85$;

Nilai Minimal (Anggaran) $=\{93,85$; $88,85 ; 80,77\}=80,77$;

Nilai Maksimal (Fisik) $=\{99,23$; $97,31 ; 86,54\}=99,23$;

Nilai Minimal $($ Fisik $)=\{99,23 ; 97,31$; $86,54\}=86,54$;

- Matriks Utility Anggaran (lihat Gambar 4.27) 
Triwulan 1 (Anggaran) $=((93,85-$ $80,77) /(93,85-80,77) * 100 \%)=1$

Triwulan 2 (Anggaran) $=(88,85-$ $80,77) /(93,85-80,77) * 100 \%=0,62$

Triwulan 3 (Anggaran) $=(80,77-$ $80,77) /(93,85-80,77) * 100 \%=0$

- Matriks Utility Fisik (lihat Gambar 4.27)

Triwulan 1 (Fisik) = $((99,23-$ $86,54) /(99,23-86,54) * 100 \%)=1$

Triwulan 2 (Fisik) $=(97,31-$ $86,54) /(99,23-86,54) * 100 \%)=0,85$

Triwulan 3 (Fisik) $=(80,77-$ $86,54) /(99,23-86,54) * 100 \%)=0$

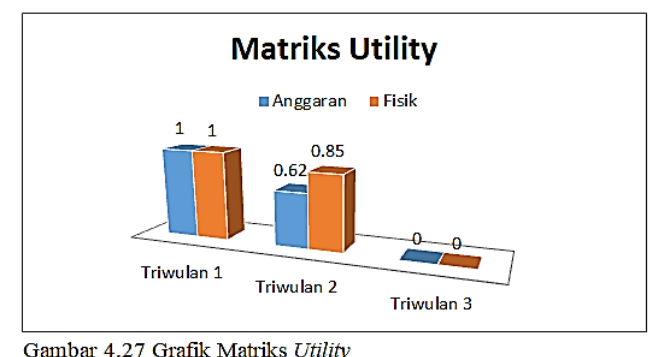

\section{- Menghitung Nilai Akhir}

Nilai Hasil Anggaran (lihat Gambar 4.28)

Triwulan 1 (Anggaran) $=0,3 * 1=$ 0,3

Triwulan $2($ Anggaran $)=0,3 * 0,62=$ 0,186

Triwulan 3 (Anggaran) $=0,3 * 0 \quad=0$

Nilai Hasil Fisik (lihat Gambar 4.28)

Triwulan 1 (Fisik) $=0,7 * 1 \quad=0,7$

Triwulan $2($ Fisik $)=0,7 * 0,85=$ 0,595

Triwulan $3($ Fisik $)=0,7 * 0 \quad=0$

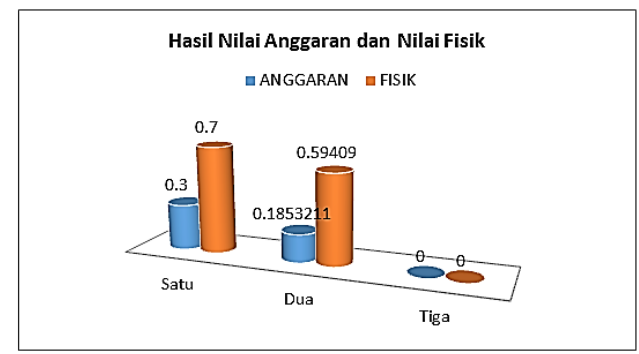

Gambar 4.28 Hasil Nilai Kinerja Anggaran dan Fisik
Nilai Akhir Triwulan $1=0,3+0,7=$ 1 ;

Nilai Akhir Triwulan $2=0,185+$ $0,594=0,779$;

Nilai Akhir Triwulan $3=0$;

Berdasarkan hasil akhir data triwulan (alternatif) diatas, maka dapat ditarik kesimpulan bahwa menurut metode SMART triwulan pertama hingga triwulan ketiga kinerja unit kerja menurun dari nilai 1 pada triwulan I, 0,78 pada triwulan II, hingga bernilai 0 pada triwulan III. Penurunan tersebut disebabkan karena output atau indikator dalam menentukan nilai kriteria banyak yang tidak mencapai target.

c. Perhitungan Hasil Akhir untuk Nilai Capaian Kinerja PNUP

Nilai Kinerja Triwulan I = $93,85 * 30 \%+99,23 * 70 \%=97,62$

Nilai Kinerja Triwulan II = $88,85 * 30 \%+97,31 * 70 \%=94,77$

Nilai Kinerja Triwulan III= $80,77 * 30 \%+86,54 * 70 \%=84,81$
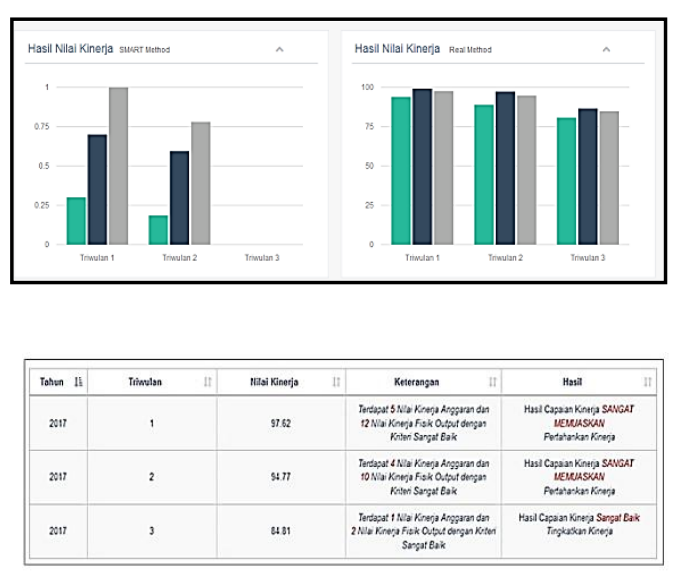

Gambar 4.28 Hasil Rekomendasi Keputusan

Dengan penentuan nilai tertinggi dan terendah serta penentuan nilai hasil metode SMART, dapat memberikan rekomendasi keputusan 
untuk para pembuat kebijakan (lihat Gambar 4.28). Sistem akan menampilkan rekomendasi keputusan melalui nilai terendah atau nilai tertinggi nilai kriteria serta hasil nilai keseluruhan.

\section{KESIMPULAN}

Dari proses perancangan, implemen tasi hingga pengujian dapat ditarik kesimpulan bahwa perkembangan capaian kinerja dari triwulan unit kerja PNUP selama tahun 2017 mengalami penurunan berdasarkan grafik. Hasil yang dicapai pada triwulan I adalah $1 \%$, pada triwulan II mengalami penurunan menjadi $0,779 \%$, dan hasil capaian triwulan III menjadi $0 \%$. Sistem Analytic Dashboard menampilkan capaian kinerja unit kerja sehingga pimpinan dapat mengawasi perkembangan capaian kinerja dari grafik analyticdashboard. Sistem Analytic Dashboard dapat menjadi opsi untuk diterapkannya salah satu konsep Bussiness Inteligence menggunakan kriteria indikator kinerja analisis dengan metode Simple Multi Attribute Rating Technique yang dinilai sesuai dengan kebutuhan organisasi.

Namun pada penelitian ini masih terdapat kekurangan. Diantaranya sampel data yang digunakan berasal dari satu instansi unit kerja dan hanya menggunakan tiga kriteria dari sampel data. Selain itu, unit kerja sebagai objek penelitian masih memiliki cakupan yang luas dalam penilaian capaian kinerja.

\section{UCAPAN TERIMA KASIH}

Penulis mengucapkan banyak terimakasih kepada pembimbing I dan II yang telah memberikan bimbingan serta kepada Unit Bagian Perencanaan
Politeknik Negeri Ujung Pandang (PNUP) yang telah membantu hingga penulis menyelesaikan jurnal ini.

\section{REFERENSI}

[1] Nugroho, Yanuar, "Teknologi Informasi dan Gerakan Sosial Indonesia (Studi Penggunaan Teknologi Informasi dan Komunikasi di Kalangan Kelompok/Organisasi Masyarakat Sipil di Indonesia Bagi Perubahan Sosial)". Tesis. Inggris: Universitas Manchester,2006.

[2] Forrsights Software North American and European. Forrester Research. 2011.

[3] Maimunah dkk. 2012. Rancang Bangun Aplikasi Data Warehouse Untuk BusinessIntelligence. CSRID Journal, 4(1):27-46. Tangerang: STMIK Raharja..

[4] Vercellis, C. 2009. Business Intelligence : Data Mining and Optimization For Decision Making.

[5] Arifin, Zainal. 2012. Rancang Bangun Sistem Business Intelligence Universitas Sebagai Pendukung Pengambilan Keputusan Akademik (Studi Kasus Universitas Mulawarman). Tesis. Semarang: Universitas Diponegoro.

[6] Murti, Harry dan Veronika Agustini Srimulyan. 2013. Pengaruh Motivasi Terhadap Kinerja Pegawai Dengan Variabel Pemediasi Kepuasaan Kerja Pada PDAM Kota Madiun. Jurnal Riset Manajemen dan Akuntansi, 1(1): 10-17.Universitas Katolik Widya Mandala Madiun.

[7] Pranoto, Yosep Agus dkk. 2013. Rancang Bangun dan Analisis Decision Support System Menggunakan Metode Analytical Hierarchy Process untuk Penilaian Kinerja Karyawan. Jurnal Teknologi Informasi DINAMIK, 7(1): 91-96. Malang: Universitas Brawijaya. 
[8] Suryanto dan Muhammad Safrizal. 2015. Sistem Pendukung Keputusan Pemilihan Karyawan Teladan dengan Metode SMART (Simple Multi Attribute Rating Technique). Jurnal CoreIT, 1(2): 25-29. Pekanbaru: UIN Sultan Syarif Kasim Riau.

[9] Alter. 2002. Analisis dan Perancangan Sistem Informasi dengan Metodologi Berorientasi Objek. Dalam Journal Speed - Sistem Pendukung Keputusan Penilaian Kinerja Guru Sekolah Menengah Pertama Negeri (SMP N) 1 Pacitan (Ed. Riesda Ganevi dan Bambang Eka Purnama). Pacitan: 2014.

[10] Biro Perencanaan Sekretariat Jenderal Kemenristekdikti. 2016. Penilaian Capaian Kinerja Unit Kerja/Satuan Kerjadalam Rangka Pemberian Tunjangan Kinerja di Lingkungan Kemenristekdikti.

[11] Daqiqil, Ibnu. 2011. Framework CodeIgniter.

[12] Eckerson, Wayne. 2005. Deploying Dashboard and Scorecards.

[13] Fatta, Hanif Al. 2007. Analisis dan Perancangan Sistem Informasi Untuk Keunggulan Bersaing Perusahaan Dan Organisasi Modern. Cetakan ke-1. Yogyakarta: ANDI.

[14] Hariyanti, Eva. 2008. Pengembangan Metodologi Pembangunan Information Dashboard Untuk Monitoring Kinerja Organisasi. Paper yang disajikan dalam Konferensi dan Temu Nasional Teknologi Informasi dan Komunikasi untuk Indonesia. Jakarta, Mei 2008.

[15] Hepifesti, Elfika dan Joko Siswanto. 2014. Pengembangan Model Dashboard Kinerja Perusahaan Pemasok Daya Listrik ke Perusahaan. Jurnal Telematika,9(1): 31-36. Bandung:Institut Teknologi Harapan Bangsa.

[16] Husni, Beni Abduloh Roy dan Ridwan. 2016. Sistem Informasi Perhitungan Capaian Kinerja Pegawai di Badan Pusat Statistik Kabupaten Garut. Jurnal Algoritma. Sekolah Tinggi Teknologi Garut.

[17] Jadno. 2014.Rancang Bangun Sistem Pendukung Keputusan Untuk Merekomendasikan Pembelian Kamera Digital Menggunakan Metode Simple Multi Attribute Rating Technique (SMART) Berbasis Web. Tesis. Pekanbaru: Universitas Islam Negeri Sultan Syarif Kasim.

[18] Nasution, Ardian Nurin. 2013. Penerapan Metode Simple Multi Attribute Rating Technique Untuk Penentuan Bintang Nararia Bhayangkara (Studi Kasus : Kepolisian Daerah Riau). Skripsi. Pekanbaru: Universitas Islam Negeri Sultan Syarif Kasim.

[19] North American and European Software Decision-Makers. 2011. CMSWire. (Online). (http://www.cmswire.com), diakses 5 September 2017.

[20] Parmenter, David. 2007. Key Performance Indicators : Developing, Implementing, And Using Winning KPI, John Wiley \& Sons, Inc.

[21] Pramudijono, Agus Hekso. 2014. Input dan Proses Data Dashboard Indikator Kinerja Utama (IKU). Business Intelligence Dashboard, (Online), (http://www.bppk.kemenkeu.go.id), diakses 23 Juli 2017.

[22] Putri, Nilda Tri dkk. 2012. Perancangan Standar Penilaian Kinerja Pemeliharaan Lampu Jalan Berdasarkan Key Performance Indicators (KPI's) (Studi Kasus di Kota Padang). Jurnal Optimasi Sistem Industri, 11(2): 225-234. Padang: Universitas Andalas.

[23] Rachman, Andi Nur dkk. 2016. Implementasi Sistem Dashboard pada Aplikasi Kependudukan (Studi Kasus: Dinas Kependudukan dan Pencatatan Sipil Kabupaten Ciamis). Makalah yang disajikan dalam Seminar 
Nasional Teknologi Informasi dan Komunikasi (SENTIKA) 2016. Yogyakarta, Maret 2016.

[24] Setiawan, Danang Yuli dkk. 2013. Perancangan Business Intelligence Dashboard Berbasis Web Untuk Pemantauan Tingkat Keberhasilan Pambangunan Ketenagakerjaan (Studi Kasus: Provinsi Jawa Timur) Jurnal Teknik POMITS 2013, 2(1): 1-6. Surabaya: Institut Teknologi Sepuluh November.

[25] Utomo, Agus Prasetyo dkk. 2013. Sistem Monitoring dan Evaluasi Kinerja Program Studi dengan Metode PerformanceDashboard. Laporan Hasil Penelitian. Semarang: Fakultas Teknologi Informasi Universitas Stikubank Semarang. 